\title{
ANALISIS ANTIOKSIDAN, TOTAL FENOL DAN KADAR KOLESTEROL PADA KUNING TELUR ASIN DENGAN PENAMBAHAN EKSTRAK JAHE
}

\author{
Tika Mei Indah Susanti, Binar Panunggal ${ }^{*}$ \\ Program Studi Ilmu Gizi Fakultas Kedokteran Universitas Diponegoro \\ Jl.Dr.Sutomo No.18, Semarang, Telp (024) 8453708, Email : gizifk@ undip.ac.id
}

\begin{abstract}
Background: The cholesterol levels in eggs yolk were exactly high, resulting excessive consumption of cholesterol have a negative impact because it can increase of free radicals in the body. Ginger is a spice that contains active phenolic compound such as gingerol and shaogaol has an effect as an antioxidant. Ginger extracts addition on process of salty eggs, making to increase antioxidant content, phenol total and cholesterol levels in egg yolk.

Objective: To analyzed of antioxidant content, phenol total and cholesterol levels in salty eggs with ginger extract variations addition.

Methods: This study was used randomized, single factor experimental design using 4 treatment variation was P0 (control or without ginger extract addition), $P 1_{A}$ (Zingiber officinale var. Officinarum), $P 1_{B}$ (Zingiber officinale var. Ammarum), and $P l_{C}$ (Zingiber officinale var. Rubrum) using the same method during storage (14 days). Analysis antioxidant contents using the DPPH method, phenol total content using Folin-Ciocalteu method and cholesterol levels using CHOD-PAP method.

Result: Antioxidant content, phenol total and cholesterol with ginger extract addition, as much 15,82-42,51\%; 13,8$43 \mathrm{mg}$ GAE/gr; 813,95-720,08 mg/100gr egg yolk. There were significant differences in all variable groups $\left(P 1_{A}, P 1_{B}\right.$, $\left.P 1_{C}\right)$. The highest different antioxidant content, phenol total and decreased cholesterol levels were $P 1_{C} 32,9 \%, 38,33$ $\mathrm{mg}$ GAE/gr and 143,67 $\mathrm{mg} / 100 \mathrm{gr}$ egg yolk.

Conclusion: The highest different antioxidant content, phenol total and decreased cholesterol levels were salty egg yolk added by red ginger extract $\left(P 1_{C}\right)$ than $P 1_{B}$ and $P 1_{A}$.

Keywords: Antioxidant, phenol total, cholesterol level, ginger extract, salty egg yolks.
\end{abstract}

\begin{abstract}
ABSTRAK
Latar Belakang: Kadar kolesterol pada kuning telur cukup tinggi, mengakibatkan konsumsi kolesterol berlebih dapat meningkatkan perkembangan radikal bebas dalam tubuh. Jahe mengandung senyawa fenolik aktif seperti gingerol dan shogaol yang memiliki efek antioksidan. Penambahan ekstrak jahe dalam pembuatan telur asin dapat meningkatkan kandungan antioksidan, total fenol dan kadar kolesterol kuning telur.

Tujuan: Menganalisis kandungan antioksidan, total fenol dan kadar kolesterol pada telur asin dengan penambahan variasi ekstrak jahe.

Metode: Penelitian eksperimental dengan rancangan acak lengkap satu faktor dengan 4 variasi perlakuan yakni P0 (kontrol atau tanpa penambahan ekstrak jahe), $P 1_{A}$ (Zingiber officinale var. Officinarum), $P 1_{B}$ (Zingiber officinale var. Ammarum) dan $P 1_{C}$ (Zingiber officinale var. Rubrum) dengan lama pemeraman 14 hari. Analisis antioksidan menggunakan DPPH, total fenol menggunakan Folin-Ciocalteu dan kadar kolesterol menggunakan CHOD-PAP.

Hasil: Kandungan antioksidan, total fenol, kolesterol dengan penambahan esktrak jahe 15,82-42,51\%; 13,8-43 mg GAE/gr; 813,95-720,08 mg/100 gr kuning telur. Terdapat perbedaan kandungan antioksidan, total fenol dan kadar kolesterol yang bermakna pada semua kelompok perlakuan $\left(P 1_{A}, P 1_{B}, P 1_{C}\right)$. Perbedaan selisih kandungan antioksidan, total fenol dan kadar kolesterol tertinggi yaitu pada P1 $1_{C}$ sebesar 32,9\%, 38,33 mg GAE/gr dan 143,67 mg/l00 gr kuning telur.
\end{abstract}

Kesimpulan: Perbedaan selisih kandungan antioksidan, total fenol dan penurunan kadar kolesterol tertinggi terdapat pada kuning telur asin dengan penambahan ekstrak jahe merah $\left(P 1_{C}\right)$ dibandingkan dengan $P 1_{A} d a n P 1_{B}$.

Kata kunci : Antioksidan, total fenol, kuning telur asin, kolesterol, gingerol, shaogaol.

\section{PENDAHULUAN}

Telur merupakan salah satu makanan tinggi protein. Salah satu keunggulan protein telur dibandingkan dengan protein hewani lainnya adalah daya cernanya yang tinggi, artinya setiap gram protein yang masuk akan dicerna didalam tubuh secara sempurna. ${ }^{1}$ Telur unggas mengandung air, protein, lemak, karbohidrat, vitamin, mineral dan antioksidan. Pada umumnya masyarakat mengkonsumsi dengan mengolahnya menjadi telur dadar, telur rebus dan sebagai bahan pencampur dalam pembuatan kue, telur asin dan lain-lain. ${ }^{2}$ Telur memiliki sifat mudah rusak sehingga daya simpan tidak lama. ${ }^{2}$

Kandungan gizi telur itik segar per 100 gr yaitu mengandung energi sebesar $189 \mathrm{kal}$, protein $13,1 \mathrm{gr}$, lemak $14,3 \mathrm{gr}$, karbohidrat $0,8 \mathrm{gr}$, kalsium $56 \mathrm{mg}$ sedangkan kandungan gizi telur itik asin

\footnotetext{
${ }^{*}$ Penulis Penanggungjawab
} 
yaitu energi sebesar $195 \mathrm{kal}$, protein 13,6 gr, lemak 13,6 kal, karbohidrat 1,4 gr dan kalsium sebesar 120 mg. ${ }^{4,5}$ Telur yang digunakan dalam pembuatan telur asin adalah telur itik, karena memiliki pori-pori kulit yang lebih lebar dibandingkan dengan telur unggas lainnya..$^{5}$ Dalam proses pembuatan telur asin, garam berfungsi sebagai pencipta aroma asin dan bahan pengawet karena dapat mengurangi kelarutan oksigen, menghambat kerja enzim proteolitik, dan menyerap air dari dalam telur sehingga kandungan zat gizi tidak banyak rusak atau hilang. ${ }^{5,6}$ Telur itik yang diolah melalui proses pengasinan dapat meningkatkan mutu gizinya. ${ }^{5}$

Menurut Direktorat Gizi Departemen Kesehatan RI, kadar lemak pada bagian kuning telur itik adalah 35\%, sedangkan kadar lemak kuning telur ayam adalah $31,9 \% .{ }^{4}$ Kuning telur memiliki kadar kolesterol yang tergolong cukup tinggi yaitu $1075 \mathrm{mg} /$ 100gr kuning telur, menyebabkan konsumsi telur secara berlebihan berdampak negatif untuk kesehatan. ${ }^{7}$

Terjadinya peningkatan kadar kolesterol dalam tubuh berperan dalam perkembangan radikal bebas yang melebihi kapasitas antioksidan dalam tubuh yang akan meningkatkan resiko timbulnya berbagai penyakit seperti kanker, diabetes, penyakit jantung dan lainnya. ${ }^{12}$ Seiring dengan meningkatnya prevalensi penyakit degeneratif sehingga konsumsi makanan dengan tinggi antioksidan dan rendah kolesterol menjadi suatu kebutuhan yang dibutuhkan oleh setiap individu. ${ }^{8}$

Jahe merupakan rempah kaya antioksidan. Jahe mengandung komponen volatil dan non volatil yang memberikan bau yang khas dan rasa pedas. Komponen non volatil disebut juga oleoresin yang merupakan gambaran utuh dari kandungan jahe yaitu minyak atsiri yang terdiri dari gingerol, shaogaol dan resin. Menurut penelitian Hernani, jahe merah mempunyai kandungan minyak atsiri dan ekstrak yang dapat larut dalam alkohol sebesar 3,9\% dan 9,93\% lebih tinggi dibandingkan dengan jahe emprit (3,5\% dan 7,29\%) dan jahe putih $(2,5 \%$ dan $5,81 \%) .{ }^{10}$ Komponen oleoresin jahe menentukkan besarnya kandungan antioksidan dan total fenol pada masing-masing jahe. ${ }^{11}$

Senyawa fenol merupakan suatu senyawa yang memiliki cincin aromatik dengan satu atau lebih gugus hidroksil yang berfungsi sebagai antioksidan, kemampuannya dalam menstabilkan radikal bebas, yaitu dengan memberikan atom hidrogen secara cepat kepada radikal bebas, sedangkan radikal yang berasal dari antioksidan senyawa fenol ini akan lebih stabil daripada radikal bebasnnya. ${ }^{10}$ Berdasarkan penelitian Rehman et al, senyawa fenol dapat berfungsi sebagai antioksidan karena kemampuannya meniadakan radikal bebas dan radikal perioksida sehingga efektif dalam menghambat oksidasi lipida. ${ }^{11}$ Jahe banyak mengandung komponen phenollic aktif seperti gingerol dan shogaol yang memiliki efek sebagai antioksidan dan antikanker. ${ }^{11}$ Kandungan total fenol jahe merah, jahe putih dan jahe emprit berurutan yaitu sebesar $95,34 \mathrm{mg} / 100 \mathrm{gr}, 47,7 \mathrm{mg} / 100 \mathrm{gr}$, dan $61,89 \mathrm{mg} / 100$ gr. $^{13}$

Penelitian sebelumnya menunjukkan bahwa terdapat pengaruh peningkatan kandungan antioksidan pada telur asin dengan penambahan esktrak jahe dibandingkan dengan telur asin biasa yaitu pada telur asin dengan penambahan ekstrak jahe 28,718\%, sedangkan pada telur asin biasa sebesar $1,585 \% .^{3}$ Telur Asin tanpa penambahan ekstrak jahe mengadung antioksidan karena pada umunya kuning telur asin mengandung antioksidan meskipun dalam jumlah kecil. Antioksidan pada telur yang sudah diketahui yaitu $\beta$-karoten yang nmemberikan pigmen warna orange pada kuning telur. ${ }^{3,5}$ Menurut penelitian, total fenol pada telur asin biasa sebanyak 2,4 mg GAE/gr, sedangkan telur asin dengan penambahan ekstrak jahe emprit menunjukkan peningkatkan total fenol dan aktivitas antioksidan yang signifikan. ${ }^{3}$ Menurut penelitian yang dilakukan oleh Purwadi et al. yaitu penggunanan ekstrak jahe pada larutan pengasinan mampu meningkatkan aktivitas enzim lipase yang mampu membuat kadar lemak semakin menurun. ${ }^{9}$

Untuk menurunkan kadar kolesterol yang terdapat pada kuning telur dan meningkatkan total fenol sebagai senyawa antoksidan digunakan ekstrak jahe dalam pembuatan telur asin. Dengan adanya penambahan ekstrak jahe dalam pembuatan telur asin diharapkan meningkatkan aktivitas antioksidan, kadar total fenol dan kadar kolesterol dalam telur asin namun tetap memperhatikan kelengkapan gizinya. Oleh karena itu, dalam penelitian ini perlu dilakukan pengujian terhadap kandungan antioksidan, total fenol dan kadar kolesterol pada telur asin dengan penambahan variasi ketiga ekstrak jahe yaitu jahe merah, jahe putih dan jahe emprit.

\section{METODE}

Penelitian yang dilakukan termasuk dalam bidang food production. Analisis kandungan antioksidan, total fenol dan kadar kolesterol pada telur asin dengan penambahan variasi jenis ekstrak jahe dilaksanakan di Laboratorium Ilmu Gizi dan Teknologi Pangan Universitas Muhammadiyah Semarang. Penyusunan proposal dan artikel pada bulan Maret - Agustus 2015. 
Penelitian ini termasuk penelitian eksperimental dengan rancangan satu faktor dengan 4 variasi perlakuan yaitu P0 (kontrol atau tanpa penambahan ekstrak jahe), $\mathrm{P}_{\mathrm{A}}$ (Zingiber officinale var. Officinarum) telur asin dengan penambahan ekstrak jahe putih, $\mathrm{P}_{\mathrm{B}}$ (Zingber officinale var. Ammarum) telur asin dengan penambahan ekstrak jahe emprit dan $\mathrm{P}_{\mathrm{C}}$ (Zingiber officinale var. Rubrum) telur asin dengan penambahan ekstrak jahe merah. Setiap perlakuan dilakukan uji aktivitas antioksidan, total fenol dan kadar kolesterol sebanyak tiga kali pengulangan secara duplo.

Proses pembuatan telur asin dapat dilihat pada alur kerja pada Lampiran 1. Dalam pembuatan telur asin dipilih telur yang bermutu baik dengan ukuran sama. Telur didapat dari Desa Siasem Wanasari Brebes. Jahe didapat dari petani didaerah Larangan Kabupaten Brebes. Selanjutnya adalah pembuatan ektrak jahe, dapat dilihat pada Lampiran 2. Setelah itu pembuatan adonan pengasinan, dapat dilihat pada Lampiran 3. Kemudian proses selanjutnya adalah pembalutan telur itik dengan adonan pengasinan dapat dilihat pada Lampiran 4. Kemudian sampel dilakukan analisis yang meliputi uji aktivitas antioksidan yang diperoleh melalui metode spektrofometer dengan metode DPPH (\%), total fenol diperoleh dengan metode Follin ciocalteu (mg GAE/gr) dan kadar kolesterol diperoleh dengan metode CHOD-PAP (mg). ${ }^{14-16}$

Data yang telah terkumpul dianalisis dengan uji statistik. Semua data sebelum dianalisis akan dilakukan uji normalitas data terlebih dahulu. Selanjutnya dilakukan analisis bivariat yaitu menggunakan uji statistik Anova (Analysis of Varians) satu arah untuk mengetahui perbedaan kandungan aktivitas antioksidan, total fenol, dan kadar kolesterol pada telur asin dengan penambahan esktrak jahe. Kemudian dilakukan uji lanjut apabila dari hasil uji Anova terdapat perbedaan. Uji ini digunakan untuk melihat kelompok perlakuan manakah yang terdapat perbedaan bermakna. ${ }^{17}$

\section{HASIL}

Hasil uji kandungan antioksidan, total fenol dan kadar kolesterol menunjukkan kandungan antioksidan, total fenol dan penurunan kadar kolesterol tertinggi adalah pada kuning telur asin dengan penambahan ekstrak jahe merah $\left(\mathrm{P} 1_{\mathrm{C}}\right)$ jika dibandingkan dengan jahe emprit $\left(\mathrm{P} 1_{\mathrm{B}}\right)$, jahe putih $\left(\mathrm{P} 1_{\mathrm{A}}\right)$ dan kontrol $(\mathrm{P} 0)$ secara bermakna $(\mathrm{p}=0,000)$. Hasil analisis kandungan antioksidan, total fenol dan kadar kolesterol pada telur asin dengan penambahan ekstrak jahe secara singkat dapat dilihat pada (Tabel 1).

Tabel 1. Perbedaan kandungan Antioksidan, Total fenol dan Kadar Kolesterol antar variasi perlakuan

\begin{tabular}{lllll}
\hline \multirow{2}{*}{\multicolumn{1}{c}{ Variabel }} & \multicolumn{4}{c}{ Rerata \pm SD } \\
\cline { 2 - 5 } & \multicolumn{1}{c}{ P0 } & \multicolumn{1}{c}{ P1 } & \multicolumn{1}{c}{ P1 } & P1C $^{\text {B }}$ \\
\hline Antioksidan \% & $9,60 \pm 1,14^{\mathrm{d}}$ & $15,82 \pm 1,57^{\mathrm{c}}$ & $26,14 \pm 2,09^{\mathrm{b}}$ & $42,51 \pm 3,46^{\mathrm{a}}$ \\
Total Fenol (mg GAE/ gr) & $4,6 \pm 0,018^{\mathrm{d}}$ & $13,8 \pm 0,016^{\mathrm{c}}$ & $29,3 \pm 0,043^{\mathrm{b}}$ & $43,0 \pm 0,037^{\mathrm{a}}$ \\
Kadar Kolesterol (mg/100 gr) & $863,75 \pm 22,01^{\mathrm{d}}$ & $813,95 \pm 12,26^{\mathrm{c}}$ & $759,8 \pm 15,16^{\mathrm{b}}$ & $720,08 \pm 8,984^{\mathrm{a}}$ \\
\hline
\end{tabular}

Keterangan : Angka yang diikuti huruf superscript menunjukkan perbedaan yang bermakna

Hasil uji menunjukkan bahwa terdapat jahe $\left(\mathrm{P}_{\mathrm{A}}, \mathrm{P} 1_{\mathrm{B}}, \mathrm{P} 1_{\mathrm{C}}\right)$ dan perlakuan kontrol $(\mathrm{P} 0)$ perbedaan selisih ( $\Delta$ Mean) pada kandungan secara bermakna $(\mathrm{p}=0,000)$, secara singkat dapat antioksidan, total fenol dan kadar kolesterol pada dilihat pada (Tabel 2.). telur asin dengan penambahan ketiga variasi ekstrak

Tabel 2. Perbedaan selisih kandungan antioksidan, total fenol dan kadar kolesterol

\begin{tabular}{llll}
\hline \multirow{2}{*}{ Variabel } & \multicolumn{3}{c}{$\Delta$ Mean } \\
\cline { 2 - 4 } & \multicolumn{1}{c}{$\mathbf{P 1}_{\mathbf{A}}$} & \multicolumn{1}{c}{$\mathbf{P 1}_{\mathbf{B}}$} & \multicolumn{1}{c}{$\mathbf{P 1}_{\mathbf{C}}$} \\
\hline Antioksidan \% & $6,22 \pm 0,81^{\mathrm{c}}$ & $16,54 \pm 0,75^{\mathrm{b}}$ & $32,90 \pm 1,34^{\mathrm{a}}$ \\
Total fenol (mg GAE/gr) & $9,17 \pm 0,542^{\mathrm{c}}$ & $24,67 \pm 2,02^{\mathrm{b}}$ & $38,33 \pm 1,83^{\mathrm{a}}$ \\
Kolesterol (mg/ 100 gr) & $49,7 \pm 9,03^{\mathrm{c}}$ & $83,89 \pm 6,602^{\mathrm{b}}$ & $143,67 \pm 6,60^{\mathrm{a}}$ \\
\hline
\end{tabular}

Keterangan : Angka yang diikuti huruf superscript menunjukkan perbedaan yang bermakna

Gambaran perbedaan kandungan telur asin dengan penambahan ketiga variasi ekstrak antioksidan, total fenol dan kadar kolesterol pada jahe. Dapat dilihat pada diagram 1, 2, dan 3 berikut: 


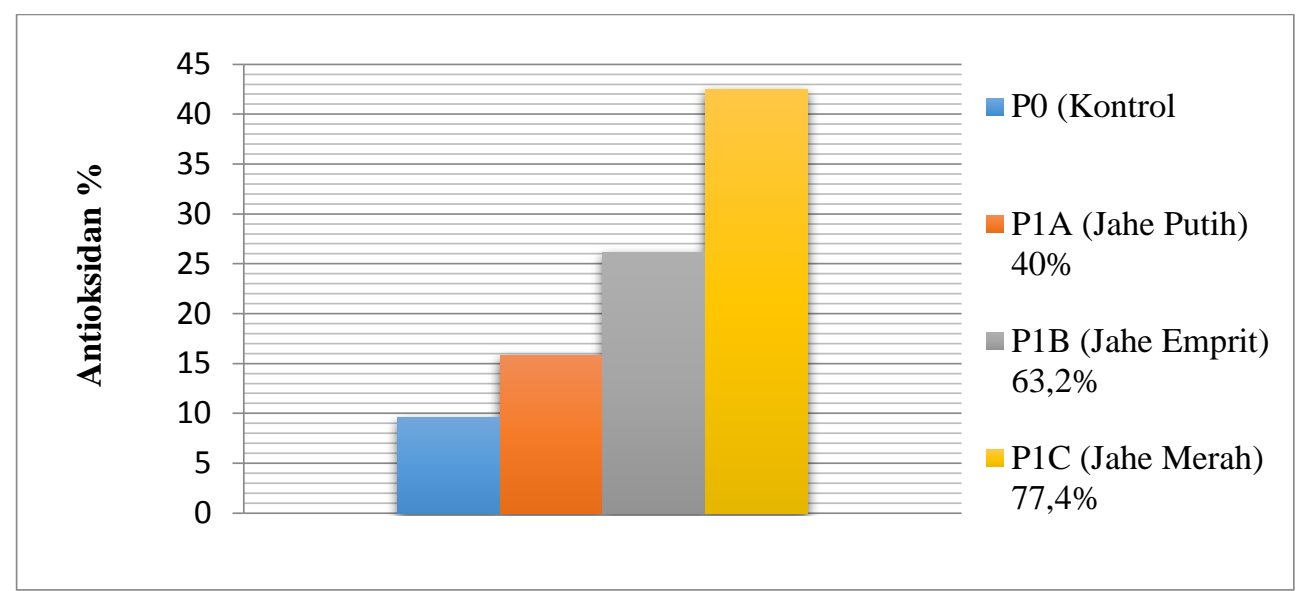

Gambar 1. Perbedaan Selisih Kandungan Antioksidan

Pada Gambar 1. menunjukkan terdapat perbedaan selisih kandungan antioksidan pada telur asin dengan penambahan ketiga variasi ekstrak jahe
$\left(\mathrm{P} 1_{\mathrm{A}}, \mathrm{P} 1_{\mathrm{B}}, \mathrm{P} 1_{\mathrm{C}}\right)$ dengan perlakuan kontrol $(\mathrm{P} 0)$ secara bermakna $(\mathrm{p}=0,000)$.

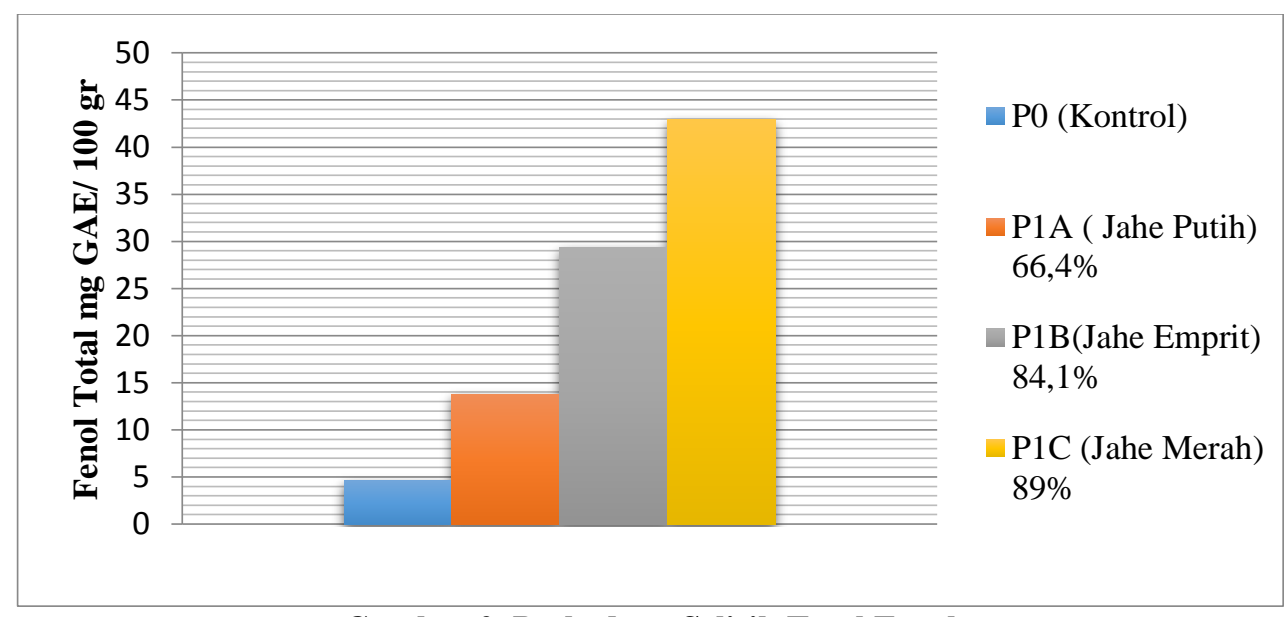

Gambar 2. Perbedaan Selisih Total Fenol

Pada Gambar 2. menunjukkan terdapat $\left(\mathrm{P} 1_{\mathrm{A}}, \mathrm{P} 1_{\mathrm{B}}, \mathrm{P} 1_{\mathrm{C}}\right)$ dengan perlakuan kontrol $(\mathrm{P} 0)$ perbedaan selisih kandungan total fenol pada telur asin dengan penambahan ketiga variasi ekstrak jahe secara bermakna $(\mathrm{p}=0,000)$.

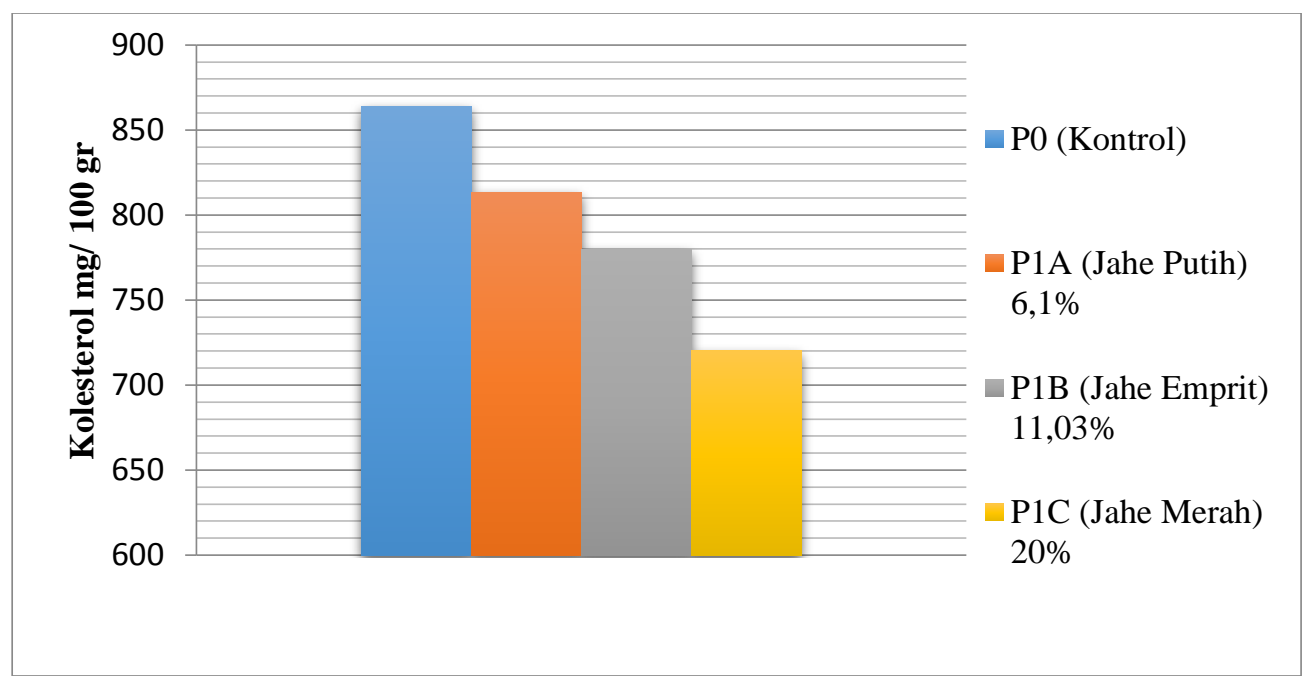

Gambar 3. Perbedaan Selisih Kadar Kolesterol 
Pada Gambar 3. menunjukkan terdapat perbedaan selisih kadar kolesterol pada telur asin dengan penambahan ketiga variasi ekstrak jahe $\left(\mathrm{P} 1_{\mathrm{A}}, \mathrm{P} 1_{\mathrm{B}}, \mathrm{P} 1_{\mathrm{C}}\right)$ dengan perlakuan kontrol $(\mathrm{P} 0)$ secara bermakna $(\mathrm{p}=0,000)$.

\section{PEMBAHASAN}

Penggaraman pada telur merupakan suatu metode pengawetan yang dapat dilakukan melalui beberapa cara yaitu dengan perendaman dalam larutan garam jenuh dan pembalutan telur dengan adonan pengasinan. ${ }^{25}$ Penambahan berbagai jenis ekstrak jahe bertujuan untuk mengetahui perbedaan kandungan antioksidan, total fenol dan kadar kolesterol pada telur asin yang sudah ditambahkan ekstrak jahe. Proses pemeraman dilakukan selama 14 hari, bertujuan supaya garam dan ekstrak jahe dalam adonan pengasinan masuk ke dalam telur. Menurut penelitian Putri, penambahan ekstrak jahe emprit pada pembuatan telur asin pada konsentrasi 75\% mempengaruhi kualitas sensoris telur asin yang meliputi warna, tekstur dan rasa. ${ }^{3}$ Telur asin dengan penambahan jahe emprit memiliki warna yang menarik yakni berwarna orange, sedangkan untuk tekstur dan rasa yaitu bertekstur masir dan sedikit berperisa jahe. ${ }^{3}$ Berdasarkan hasil penelitian yang telah dilakukan Hedi, penambahan ekstrak jahe dengan variasi lama pemeraman dapat mempengaruhi karakteristik sensoris yang meliputi parameter warna, rasa, aroma dan tekstur. Nilai dengan tingkat kesukaan paling tinggi yaitu pada telur asin yang ditambahkan ekstrak jahe dengan lama pemeraman 14 hari. $^{1}$

\section{Kandungan Antioksidan}

Telur asin dengan penambahan ekstrak jahe merah memiliki kandungan antioksidan tertinggi yakni $42,51 \%$, sedangkan antioksidan terendah terdapat pada telur asin dengan penambahan jahe putih yaitu 15,82 \%. Kandungan tersebut lebih tinggi dibandingkan dengan kandungan antioksidan pada kontrol yakni 9,6\%. Pada telur asin tanpa penambahan ekstrak jahe (kontrol) mengandung antioksidan, hal tersebut dikarenakan pada kuning telur terdapat antioksidan alami berupa $\beta$ - karoten. $\beta$-karoten tersebut memberikan pigmen warna kuning-orange pada kuning telur., ${ }^{5,19}$ Penelitian sebelumnya, menunjukkan bahwa penambahan ekstrak jahe emprit dengan konsentrasi yang sama mampu meningkatkan kandungan antioksidan pada telur asin. ${ }^{3}$ Terdapat perbedaan selisih kandungan antioksidan pada telur asin dengan penambahan ketiga jenis ekstrak jahe yaitu pada $\mathrm{P} 1_{\mathrm{C}}$ sebesar $32,9 \%, \mathrm{P} 1_{\mathrm{B}}$ sebesar $16,54 \%$, dan $\mathrm{P} 1_{\mathrm{A}}$ sebesar 6,22 $\%$. Perbedaan kandungan antioksidan pada telur asin dengan variasi penambahan ketiga ekstrak jahe terjadi karena tiap-tiap jahe memiliki komponen kimia yang berbeda-beda. Pada jahe merah memiliki oleoresin lebih tinggi dibandingkan dengan jahe putih dan jahe emprit. ${ }^{11,20}$ Menurut penelitian Hernani et al. jahe merah mempunyai kandungan minyak atsiri $(3,9 \%)$ dan ekstrak yang larut dalam alkohol (9,93\%) lebih tinggi dibandingkan jahe emprit $(3,5 \%$ dan $7,29 \%)$ dan jahe putih $(2,5 \%$ dan $5,81 \%) .{ }^{10}$ Kandungan minyak atsiri dan kelarutan menentukkan besarnya antioksidan dan total fenol yang terkandung pada jahe. ${ }^{10}$ Kandungan total fenol jahe merah, jahe putih dan jahe emprit berurutan yaitu sebesar 95,34 $\mathrm{mg} / 100 \mathrm{gr}, 47,7 \mathrm{mg} / 100 \mathrm{gr}$, dan $61,89 \mathrm{mg} / 100 \mathrm{gr} .{ }^{13}$

Antioksidan merupakan senyawa yang melindungi senyawa atau jaringan dari efek destruktif jaringan oksigen atau efek oksidasi. ${ }^{18}$ Penggunaan senyawa antioksidan semakin meningkat seiring dengan besarnya pemahaman masyarakat tentang manfaatnya. ${ }^{17}$ Antioksidan merupakan senyawa penting dalam menjaga kesehatan tubuh karena berfungsi sebagai penangkap radikal bebas yang banyak terbentuk dalam tubuh. Fungsi antioksidan digunakan sebagai upaya untuk memperkecil terjadinya proses oksidasi dari lemak dan minyak, memperkecil terjadinya proses kerusakan dalam makanan, serta memperpanjang masa pemakaian bahan dalam industri makanan. ${ }^{30}$ Beberapa komponen bioaktif dalam ekstrak jahe antara lain (6)-gingerol, (6)shogaol, diarilheptanoid dan curcumin mempunyai aktivitas antioksidan yang melebihi tokoferol. ${ }^{29}$

Hasil penelitian Manju et al. menyatakan bahwa senyawa antioksidan alami dalam jahe cukup tinggi dan sangat efisien dalam menghambat radikal bebas superoksida dan hidroksil yang dihasilkan oleh sel-sel kanker, dan bersifat sebagai antikarsinogenik dan non-toksik. ${ }^{28}$ Telur asin dengan penambahan variasi ekstrak jahe dibuat sebagai produk pangan yang bertujuan untuk memenuhi kebutuhan zat gizi dengan mengikutsertakan kandungan antioksidan pada bahan pangan. Kemampuan antioksidan pada ekstrak jahe berperan dalam peningkatan aktivitas antioksidan pada bahan makanan. ${ }^{20}$ Hasil penelitian Kikuzaki et al. menunjukkan bahwa senyawa aktif non volatil fenol seperti gingerol dan shogaol yang terdapat pada jahe terbukti memiliki kemampuan sebagai antioksidan. ${ }^{29}$ Sehingga kemampuan gingerol dan shaogaol sebagai antioksidan mampu berkontribusi dalam meningkatkan kandungan antioksidan pada telur asin. Pada telur asin terdapat kandungan $\beta$-karoten, selain sebagai prekusor vitamin A juga berperan sebagai antioksidan sekunder yang berfungsi menangkap radikal bebas 
dan mencegah reaksi berantai sehingga tidak terjadi peroksidasi lipid. $^{8}$

Antioksidan terbagi menjadi dua yaitu antioksidan enzimatik seperti superoxide dismutasse (SOD), catalase (CAT) dan glutathione peroxidase. Namun, apabila di dalam tubuh mengalami stres oksidatif, antioksidan enzimatik tersebut tidak mampu menangkal radikal bebas sehingga perlu mengasup makanan sumber antioksidan. ${ }^{8}$ Stres oksidatif ini menyebabkan peningkatan radikal bebas dan penekanan antioksidan enzimatik. ${ }^{32}$ Akibatnya tubuh perlu mengasup antioksidan nonenzimatik yang diperoleh dari sumber pangan. Antioksidan yang diasup dari luar ini fungsinya sebagai antioksidan sekunder, mekanisme kerjanya yaitu memotong reaksi oksidasi berantai radikal bebas dan menangkap radikal bebas. ${ }^{8,26}$

Kandungan antioksidan pada telur asin dengan penambahan ekstrak jahe didapatkan dari metode untuk menentukan aktivitas antioksidan suatu bahan adalah 2,2-dyphenyl-1-picryhydrazil $(\mathrm{DPPH})$. Proses reduksi senyawa DPPH oleh antioksidan yang menghasilkan penurunan intensitas warna larutan DPPH menunjukkan mekanisme antioksidan dalam menangkap radikal bebas. ${ }^{14}$ Reaksi yang terjadi adalah pembentukan $\alpha, \alpha$-diphenyl- $\beta$-picrylhydrazine melalui kemampuan antioksidan menyumbang hidrogen. Pemudaran warna mengakibatkan penurunan nilai absorbansi sinar yang dapat dilihat pada spektrofotometer. Semakin pudar warna DPPH setelah direaksikan dengan antioksidan menunjukkan aktivitas antioksidan yang semakin besar pula. ${ }^{14}$

Pada penelitian ini menunjukkan bahwa penambahan dari ketiga ekstrak jahe sebagai antioksidan alami mampu memberikan antioksidan pada bahan pangan. Kemampuan antioksidan pada ekstrak jahe mampu meningkatkan aktivitas antioksidan pada telur asin. Makanan lauk seperti telur asin yang mengandung tinggi antioksidan diharapkan selain memberikan asupan energi atau makanan utama, dapat membantu meminimalisir stress oksidatif yang menangkal radikal bebas.

\section{Kandungan fenol total}

Telur asin dengan penambahan ekstrak jahe merah memiliki kandungan total fenol tertinggi yakni $43 \mathrm{mg}$ GAE/gr sedangkan total fenol terendah terdapat pada telur asin dengan penambahan jahe putih yaitu 13,8 mg GAE/gr. Kandungan tersebut lebih tinggi dibandingkan kandungan total fenol pada telur asin tanpa penambahann ekstrak jahe yakni 4,6 mg GAE/gr. Hal ini sesuai dengan penelitian sebelumnya yang dilakukan Hedi dan
Putri, menunjukkan bahwa penambahan ekstrak jahe mampu meningkatkan kandungan total fenol yang signifikan pada telur asin, yang berperan sebagai antioksidan. ${ }^{1,3}$ Terdapat perbedaan selisih kandungan total fenol pada telur asin dengan penambahan ketiga variasi ekstrak jahe yaitu pada $\mathrm{P} 1_{\mathrm{C}}$ sebesar 38,33 mg GAE/gr, $\mathrm{P} 1_{\text {B }}$ sebesar 24,67 mg GAE/gr dan $\mathrm{P}_{\mathrm{A}}$ sebesar 9,17 mg GAE/gr. Perbedaan kandungan fenol pada telur asin dengan penambahan ketiga jenis ekstrak jahe terjadi karena pada jahe merah memiliki kandungan fenol lebih tinggi dibandingkan dengan jahe putih dan jahe emprit. ${ }^{11,20}$ Kandungan total fenol pada masingmasing jahe yaitu jahe merah, jahe putih dan jahe emprit berurutan yaitu sebesar $95,34 \mathrm{mg} / 100 \mathrm{gr}$, $47,7 \mathrm{mg} / 100 \mathrm{gr}$, dan $61,89 \mathrm{mg} / 100$ gr. $^{13}$

Hasil penelitian Kikuzaki et al. menunjukkan bahwa senyawa aktif non volatil fenol seperti gingerol dan shogaol dan senyawa turunannya yang terdapat pada jahe terbukti memiliki kemampuan sebagai antioksidan ${ }^{20,29}$ Senyawa fenolik dapat berfungsi sebagai antioksidan karena kemampuannya dalam menstabilkan radikal bebas yaitu dengan memberikan atom hidrogen kepada radikal bebas, sedangkan radikal yang berasal dari antioksidan senyawa fenol ini lebih stabil dari pada radikal bebasnya. ${ }^{1,13}$ Kemampuan antioksidan yang dimiliki oleh jahe serta kandungan senyawa fenolnya menjadi peran penting dalam peningkatan aktivitas antoksidan pada sampel yang telah direndam dalam larutan jahe. Kadar total fenol meningkat sesuai dengan peningkatan aktivitas antioksidannya. Fenol merupakan bagian dari komponen oleoresin, yakni yang berpengaruh terhadap sifat pedas jahe. ${ }^{22}$

Pengujian total fenol dalam telur asin untuk mengetahui kandungan total fenol pada telur asin yang mampu terserap pada telur. Penetapan total fenol adalah kadar total fenol yang terdapat pada telur asin yang diukur absorbansinya menggunakan spektrofotometer pada panjang gelombang $765 \mathrm{~nm}$ dan dianalisis dengan reagen Follin ciocalteu. ${ }^{15}$ Berdasarkan penelitian terdahulu, senyawa fenol dapat berfungsi sebagai antioksidan karena kemampuannya meniadakan radikal bebas dan radikal perioksida sehingga efektif dalam menghambat oksidasi lipida. ${ }^{11}$ Pada penelitian ini membuktikan bahwa peningkatan total fenol berpengaruh pada peningkatan kandungan antioksidan, semakin tinggi total fenol maka kandungan antioksidan semakin tinggi. Perbedaan kandungan total fenol pada telur asin dengan penambahan ketiga jenis jahe terjadi karena setiap jenis jahe memiliki jumlah kandungan senyawa fenolik yang berbeda-beda. ${ }^{13,20}$ 


\section{Kadar Kolesterol}

Telur asin dengan penambahan ekstrak jahe merah memiliki penurunan kadar kolesterol tertinggi yakni $720,08 \mathrm{mg} / 100$ gr kuning telur, sedangkan penurunan kadar kolesterol terendah terdapat pada telur asin dengan penambahan jahe putih yaitu $813,95 \mathrm{mg} / 100$ gram kuning telur. Kandungan kolesterol tersebut lebih rendah dibandingkan kandungan kolesterol pada telur asin tanpa penambahann ekstrak jahe yakni 863,75 $\mathrm{mg} / 100$ gr kuning telur. Terdapat perbedaan selisih kadar kolesterol pada telur asin dengan penambahan ketiga jenis ekstrak jahe yaitu pada $\mathrm{P} 1_{\mathrm{C}}$ sebesar $143,67 \mathrm{mg} / 100 \mathrm{gr}$ kuning telur, $\mathrm{P} 1_{\mathrm{B}}$ sebesar 83,89 $\mathrm{mg} / 100$ gr kuning telur dan $\mathrm{P} 1_{\mathrm{A}}$ sebesar 49,7 $\mathrm{mg} / 100$ gr kuning telur. Beberapa komponen bioaktif dalam ekstrak jahe antara lain (6)-gingerol, (6)-shogaol, diarilheptanoid dan curcumin mempunyai aktivitas antioksidan yang melebihi tokoferol. ${ }^{29}$ Penurunan kandungan kolesterol pada kuning telur berkaitan dengan peran dari antioksidan, hasil penelitian menunjukkan antioksidan fenolik seperti gingerol, shaogaol dan kandungan kurkumin pada jahe dapat digunakan untuk mencegah atau menghambat autooksidasi lemak serta menurunkan sintesis lemak..$^{23,24}$

Konsumsi makanan tinggi kolesterol menyebabkan meningkatnya kadar kolesterol dalam tubuh. Hal tersebut berperan dalam perkembangan radikal bebas dalam tubuh yang melebihi kapasitas antioksidan yang dapat meningkatkan resiko timbulnya berbagai penyakit seperti kanker, penyakit jantung koroner, atherosklerosis dan lainnya. ${ }^{12}$ Oleh karena itu, dengan penambahan esktrak jahe pada pembuatan telur asin dapat menurunkan kadar kolesterol pada kuning telur. Antioksidan pada ekstrak jahe dapat menangkap radikal bebas yang dihasilkan selama tahap propagasi dari lemak atau minyak dengan cara mendonasikan radikal hidrogen sehingga radikal lemak tidak aktif pada tahap propagasi yang akan merusak lemak. ${ }^{23,24}$ Saragih et al. menyebutkan bahwa penambahan ekstrak jahe merah memberikan pengaruh nyata terhadap angka peroksida minyak kacang tanah. Hal tersebut menghambat terjadinya oksidasi minyak pada kacang tanah, yang menunjukkan bahwa ekstrak jahe merah dapat menghambat oksidasi lipida dengan menyumbangkan radikal hidrogennya ke radikal peroksil lipida membentuk hidroperoksida lipida. Akibatnya tidak terjadi propagasi radikal bebas hidroperoksida, hal ini berkaitan dengan kandungan senyawa fenol pada jahe merah yang berfungsi sebagai antioksidan. ${ }^{31}$
Hal ini sesuai dengan penelitian Irawan, bahwa penggunaan ekstrak jahe spada larutan pengasinan mampu meningkatkan aktivitas enzim lipase karena kandungan antioksidan pada jahe yang cukup tinggi. Aktivitas enzim lipase mampu membuat kadar lemak pada telur asin menurun, dimana mayoritas lemak pada kuning telur adalah kolesterol. $^{23}$ Enzim lipase berperan dalam menghidrolisis lemak menjadi gliserol dan asam lemak. ${ }^{9,23}$ Perbedaan penurunan kolesterol pada telur asin dengan penambahan ketiga jenis ekstrak jahe tersebut karena tiap jahe memiliki kandungan antioksidan dan kandungan senyawa fenol yang berbeda. $^{27}$

Pada penelitian ini menunjukkan, penambahan ketiga variasi ekstrak jahe dalam pembuatan telur asin mampu menurunkan kadar kolesterol pada kuning telur. Makanan lauk seperti telur asin yang mengandung tinggi antioksidan dan rendah kolesterol diharapkan selain memberikan asupan energi atau makanan utama juga mengandung senyawa seperti antioksidan dan total fenol untuk mengurangi perkembangan radikal bebas yang dapat memyebabkan stres oksidatif pada tubuh.

\section{SIMPULAN}

Terdapat perbedaan kandungan antioksidan, total fenol dan kadar kolesterol yang bermakna antar kelompok perlakuan. Telur asin dengan penambahan ekstrak jahe merah memiliki kandungan antioksidan, total fenol tertinggi dan kandungan kolesterol terendah yakni $42,51 \%$; 43 mg GAE/gr dan $720,08 \mathrm{mg} / 100$ gr kuning telur dibandingkan dengan penambahan ekstrak jahe lainnya. Perbedaan selisih kandungan antioksidan, total fenol dan penurunan kolesterol tertinggi pada telur dengan penambahan ekstrak jahe merah yakni $32,90 \%$; $38,33 \mathrm{mg} \mathrm{GAE} / \mathrm{gr}$ dan $143,67 \mathrm{mg} / 100 \mathrm{gr}$ kuning telur.

\section{DAFTAR PUSTAKA}

1. Suryatno, H. Basito. Widowati E. Kajian Organoleptik Aktivitas Antioksidan Total Fenol pada Variasi Lama Pemeraman Telur Asin yang Ditambah Ekstrak Jahe (Zingiber officinale Roscoe). Jurnal Teknosains Pangan Vol 1 No 1 Oktober 2012. Universitas Sebelas Maret.

2. Kastaman R. Sudaryanto. Nopianto B, H. Kajian Proses Pengasinan Telur Metode Reverse Osmosis pada Berbagai Lama Perendaman. Jurnal Teknologi Industri Pertanian Vol. 19(1), 30-39. Jurusan Teknik dan Manajemen Industri Pertanian, Fakultas Teknologi Industri Pertanian, Universitas Padjajaran. Bandung 
3. Putri, I S. Pengaruh Penambahan Ekstrak Jahe (Zingiber officinale Roscoe) terhadap Aktivitas Antioksidan, Total fenol, dan Karakteristik Sensoris pada Telur Asin.[Skripsi]. Universitas Sebelas Maret Surakarta. 2011.

4. Direktosrat Gizi Departemen Kesehatan RI. Daftar Komposisi Bahan Makanan. Bharata Karya Aksara. Jakarta. 2003.

5. Asih, N. Kualitas Sensoris dan Antioksidan Telur Asin dengan Penggunaan Campuran $\mathrm{KCl}$ dan Ekstrak Daun Jati. [Skripsi]. Universitas Sebelas Maret. 2010.

6. Oktaviani H, karida N, Utami N. Pengaruh Pengasinan terhadap Kandungan Zat Gizi Telur Bebek yang diberi Limbah Udang. Journal Life Science 1 (2) (2012). Jurusan Biologi, FMIPA, Universitas Negeri Semarang.

7. S. C. Yang and K. H. Chen. The Oxidation of Cholesterol in the Yolk of Selective Traditional Chinese Egg Products. Journal of Poultry Science 80:370-375. 2001. Downloaded from http://ps.oxfordjournals.org/ by guest on September 7, 2015

8. Winarsi H. Antioksidan alami dan radikal. Yogyakarta: Kanisius: 2007.

9. Faiz H, Thohari I, Purwadi. Pengaruh penambahan sari temulawak (Curcuma xanthorrhiza) terhadap total fenol, kadar garam, kadar lemak dan tekstur telur asin. Jurnal Ilmu Peternakan 24 (3):38 - 44 ISSN: 0852-3581. Universitas Brawijaya. http://jiip.ub.ac.id.

10. Hernani dan E. Hayani. 2001. Identification of chemical components on red ginger (Zingiber officinale var. Rubrum) by GC-MS. Proc. International Seminar on natural products chemistry and utilization of natural resources. UI-Unesco, Jakarta : 501-505

11. Rehman, R., M. Akram, N. Akhtar, Q. Jabeen, T. Saeed, S.M.A. Shah, K. Ahmed, G. Shaheen dan H.M. Asif. 2011. Zingiber officinale Roscoe (pharmacological activity). Journal of Medicinal Plants Research. 5: 344-348.

12. Krisnansari D. Kartasurya M I. Rahfiludin M. Suplementasi Vitamin E dan Profil Lipid Penderita Dislipidemia: Studi pada Pegawai Rumah Sakit Profesor Margono Soekarjo Purwokerto. Volume 45, Nomor 1, Tahun 2011. Program Studi Ilmu Gizi Masyarakat Universitas Diponegoro.

13. Oboh G. Akinyemi A. Ademiluyi A. Antioxidant and inhibitory effect of red ginger and white ginger on $\mathrm{Fe}^{2+}$ induced lipid peroxidation in rat. Journal Experimental and Toxicology Pathology 64 (2012) 31-36. Journal available at science direct:www.elsevier.de/etp

14. Molyneux $P$. The use of stable free radical dipheylpicryl-hydrazyl (DPPH) for estimating antioxidant activity. Songklanakarin Journal of Science Technology. 2004;26;211-9.

15. Hidayati Nur. Teknologi Pengasinan Telur dengan Perendaman Media Teh Hijau (Camellia sinensis) sebagai Penurun Kadar Kolesterol Hasil Olahan. Universitas Setia Budi.

16. Tupe, R., Kemse N. and Khaire. 2013. Evaluation of antioxidant potential and total phenolic content of selected indian herbs powder extracts. International Food Research Journal. 20 (3):1053 1063.

17. Sopiyudin Dahlan M. Statistik untuk Kedokteran dan Kesehatan. Jakarta: Salemba Medika: 2010.

18. Marsono Y. Prospek Pengembangan Makanan Fungsional. Jurnal Teknologi Pangan dan Gizi, Vol. 7 No. 1 April 2008.

19. Winarti S. Makanan Fungsional. Graha ilmu. Yogyakarta. 2010.

20. Hernani, Winarti C. Kandungan Bahan Aktif Jahe dan Pemanfaatannya dalam Bidang Kesehatan. Balai Besar Penelitian dan Pengembangan Pasca Panen Pertanian. Bogor.

21. Shukla Y. Singh M. Cancer preventive properties of ginger: A brief review. Journal of Food and Chemical Toxicology 45 (2007) 683-690. Available online at www.sciencedirect.com.

22. Widiyanti, Ratna. F. 2009. Analisis Kandungan Jahe. [Skripsi]. Fakultas Kedokteran Universitas Indonesia. Jakarta.

23. Irawan, B. dan M. Septiana. Efek Komposisi Tanah dan Biofarmaka terhadap Penurunan Kadar Kolesterol pada Pengasinan Telur Itik. Journal of Agroscientiae 2012. 19 (2):0854-2333.

24. Septiana A T, Muchtadi D, Zakaria F R. Aktivitas Antioksidan Ekstrak Dikhlorometana dan Air Jahe (Zingiber Officinale Roscoe) pada Asam Linoleat. Jurnaal Teknologi dan Industri Pangan, vol XIII No.2. 2002.

25. Koswara, S. 2009. Teknologi Pengolahan Telur (teori dan praktek). eBook. Universitas Muhammadiyah Semarang. http://tekpan.unimus.ac.id.(diakses pada 10 April 2015).

26. Bubols GB, Vianna DR, Medina-Remon A, Poser G, Lamuela-Raventos, RM, Eifler-Lima VL, et al. The antioxidant activity of coumarins and flavonoids. Mini-Reviews in Medicinal Chemistry. 2013; 13 (3): 318-34.

27. Wuri Andarwulan, Fitri Faradila. Senyawa fenolik pada beberapa sayuran indigenous dari Indonesia. Journal of Southeast Asian Food and Agricultural Science and Technology (Seafast) Center Research and Community Service Institution Bogor Agricultural University. 2012.

28. Manju, V. dan N. Nalini. 2005. Chemopreventive efficacy of ginger, a naturally occurring anticarcinogen during the initiation, post initiation stages of 1, 2 dimethyl hydrazine-induced colon cancer. Clin Chim Acta. 358: 60-67

29. Kikuzaki, H. and Nakatami, N.1993. Antioxidant Effects of Some Ginger Constituents. Journal Food science. 58 (6):1407-1410.

30. Raharjo, M. Tanaman Berkhasiat Antioksidan. Penebar Swadaya. Jakarta. 2005 
31. Saragih J. Assa J. Langi T. Aktivitas Antioksdian Ekstrak Jahe Merah (Zingiber officinale var. Rubrum) Menghambat Oksidasi Minyak Kacang Tanah (Arachis hypogaea L). Jurnal Teknologi Pangan Fakultas Pertanian. UNSRAT.

32. R.I. Shobha, C.U. Rajeshwari, B. Andallu. Oxidative Stress and Antioxidant Herbs and Spices in Cancer Prevention. Handbook. 2014. Chapter 9. Food Science and Nutrition Division, Sri Sathya Sai Institute of Higher Learning, Anantapur Campus, Anantapur, Andhra Pradesh, India. 